\title{
Mouse Toxicity Induced by Lipids and Cell Walls Isolated from Actinomycetes
}

\author{
By SERPUÍ M. EKIZLERIAN, SEBASTIÃO L. BRANDÃO FILHO AND \\ CÉLIO L. SILVA* \\ Department of Parasitology, Microbiology and Immunology, School of Medicine of Ribeirão \\ Preto, University of São Paulo, 14100 Ribeirão, SP, Brazil
}

(Received 11 November 1985; revised 24 March 1986)

\begin{abstract}
The possibility was examined that the toxicity induced in mice by Actinomadura madurae, 'Streptomyces pelletieri' and Nocardia brasiliensis was due to lipid and cell-wall constituents. Mice were inoculated intraperitoneally with heat-killed bacteria, lipid extracts and cell-wall preparations emulsified in mineral oil: toxicity was evaluated by recording weight loss and deaths. Killed cells and cell-wall preparations of all three actinomycetes produced a pronounced loss of body weight, tissue necrosis, splenomegaly, a granulomatous inflammation and sometimes death. Mice inoculated with lipid extracts from $A$. madurae and 'S. pelletieri' neither died nor showed toxic effects, but mice injected with lipids isolated from $N$. brasiliensis did suffer toxic effects. They showed more marked wasting symptoms than observed after inoculation of heat-killed bacteria or of the cell-wall preparation.
\end{abstract}

\section{INTRODUCTION}

Actinomadura madurae, 'Streptomyces pelletieri' and Nocardia brasiliensis are actinomycetes which cause a chronic granulomatous disease in man, commonly called mycetoma and characterized by the presence of localized swollen and hard lesions similar to tumours. The aetiological agent penetrates the host by traumatic inoculation, and develops in the subcutaneous tissue into numerous filaments approximately $1 \mu \mathrm{m}$ in diameter, which proliferate in the form of microcolonies (grains or granules) and form conduits and sinuses that can reach connective and bone tissue. The granules detected in the lesions are associated with the formation of pus and with tissue necrosis (Conant et al., 1971; Rippon, 1982). The mycetoma granules are normally surrounded by inflammatory cell infiltrates, with polymorphonuclear cells encountered in the more adjacent region. Mononuclear cells characterized as macrophages are observed at the periphery of the lesion (Rippon, 1982). Giant cells may occasionally be observed near the surface of these abscesses. In infections of long duration there is granulation of peripheral tissue, in which abundant lymphocytes and other plasma cells are detected. The abscesses tend to branch out, producing fistulae in the skin and chronic draining sinuses. Characteristically, mycetomas are more frequently encountered in the feet or legs, but they can also appear in other parts of the body exposed to the contaminated environment. In general, they occur in rural workers, especially in hot climates, with cases reported in the tropical and subtropical regions of India, Mexico, USA, Sudan, Senegal, Nigeria, Abyssinia, Venezuela and Brazil (Conant et al., 1971; Rippon, 1982; Cross et al, 1976).

In view of the lack of studies on the bacterial products involved in the biochemical process triggered in these chronic infections, the present investigation was done to examine the possible correlation between the lipid and cell-wall constituents of $N$. brasiliensis, 'S. pelletieri' and $A$. madurae and their pathogenicity. 


\section{METHODS}

Bacterial strains and culture conditions. Actinomadura madurae 956, 'Streptomyces pelletieri' 293 and Nocardia brasiliensis 519 were obtained from Dr Carlos S. Lacaz, Faculty of Medicine, University of São Paulo, Brazil. $A$. madurae and $N$. brasiliensis were cultured at $37^{\circ} \mathrm{C}$ for $15 \mathrm{~d}$ in a medium containing $10 \mathrm{~g}$ yeast extract, $10 \mathrm{~g}$ glucose and $1 \mathrm{~g}$ sodium chloride in 1 litre distilled water. 'S. pelletieri' was cultured under the same conditions except that the medium contained $10 \mathrm{~g}$ Bacto-Peptone (Difco) and $20 \mathrm{~g}$ glucose in 1 litre distilled water. The cells were autoclaved, harvested by centrifugation at $5000 \mathrm{~g}$ for $5 \mathrm{~min}$ and washed seven times with distilled water.

Lipid extraction. Lipids were extracted by soaking the cells in chloroform/methanol $(2: 1, \mathrm{v} / \mathrm{v})$, with stirring, at room temperature for $2 \mathrm{~h}$. The extracts were separated by centrifugation at $10000 \mathrm{~g}$ for $5 \mathrm{~min}$ and the pellet, suspended in the same solvent mixture, was re-extracted three more times. The combined extracts were reduced to dryness on a rotary evaporator and extracted with diethyl ether as described by Silva \& Ioneda (1977a) to eliminate non-lipid residues.

Lipid analysis. Lipid extract was analysed by thin-layer chromatography (TLC) on plates coated with silica gel $\mathbf{F}_{254}$ (Merck). The following solvent systems were used: solvent $\mathrm{A}, \mathrm{n}$-hexane/diethyl ether/acetone/acetic acid $(70: 30: 11: 1$, by vol.), and solvent $B$, chloroform/acetone/methanol/water $(50: 60: 2 \cdot 5: 3$, by vol.). Lipids on TLC plates were detected by exposure to iodine vapour. Sugar-containing lipids were revealed with anthrone/sulphuric acid (Silva \& Ioneda, 1977 b. The following standard lipids were used: palmitic acid and triglycerides (Sigma); noncardomycolic acid and trehalose dimycolate (purified from Nocardia asteroides as described by Silva et al., 1979).

Cell-wall preparations. The lipid-extracted cell residues were disrupted by ultrasonic vibration at $200 \mathrm{~W}$ for 3 min (Braun Labsonic 1510). This process was repeated six times. The walls were collected and washed with distilled water by centrifugation at $10000 \mathrm{~g}$ for $10 \mathrm{~min}$.

Partial fractionation of walls. This was done by alkaline extraction as described by Kanetsuna et al. (1972). Briefly, walls were suspended in $1 \mathrm{M}-\mathrm{NaOH}\left(10 \mathrm{mg} \mathrm{ml}^{-1}\right)$ and gently stirred at room temperature for $1 \mathrm{~h}$. After centrifugation at $5000 \mathrm{~g}$ for $10 \mathrm{~min}$, the supernate was collected, the procedure was repeated four times and all the supernates were pooled. The alkali-insoluble sediment was washed several times with water until the washings reached $\mathrm{pH} 7$, and then once with ethanol, followed by acetone, and diethyl ether. The resulting white powder was called fraction F1. The pooled supernates were neutralized with acetic acid and left to stand overnight at $4{ }^{\circ} \mathrm{C}$, after which a precipitate had formed. The suspension was centrifuged as before. The precipitate and the supernate were collected, dialysed separately against distilled water and freeze-dried, yielding fractions F2 (alkali-soluble and precipitable with acid) and F3 (alkali-soluble and nonprecipitable with acid).

Animals. Male Swiss mice 4 to 6 weeks old weighing 19.0 to $21.0 \mathrm{~g}$ were used.

Toxicity. The material to be tested for toxicity was dissolved in mineral oil (Nujol). Before use, the clear solutions were heated to $56^{\circ} \mathrm{C}$ and subjected to ultrasonic vibration for $5 \mathrm{~min}$ using a probe of $9 \mathrm{~mm}$ diameter at $100 \mathrm{~W}$. The toxicity of heat-killed bacteria, lipid extracts and cell-wall preparations was evaluated by inoculating mice intraperitoneally at $2 \mathrm{~d}$ intervals with five $200 \mu \mathrm{g}$ doses in $0.1 \mathrm{ml}$ mineral oil and by recording weight loss and deaths. Dead mice were examined by autopsy and the lungs, spleen and liver inspected for gross lesions. Control groups were given corresponding amounts of mineral oil alone. Experiments were carried out over a period of $30 \mathrm{~d}$.

\section{RESULTS}

Heat-killed $N$. brasiliensis, $A$. madurae and 'S. pelletieri', and their respective lipid extracts and cell-wall preparations, were inoculated into mice intraperitoneally $(5 \times 200 \mu \mathrm{g})$ in $0.1 \mathrm{ml}$ mineral oil and the variations in body weight and mortality were observed for $30 \mathrm{~d}$. Results from a typical experiment are shown in Fig. 1 and Table 1.

In the case of $A$. madurae (Fig. $1 c$, Table 1), no significant variations in body weight were observed in the animals inoculated with the lipid extract when compared to the controls injected with mineral oil alone, and all animals survived the experimental period. In contrast, the animals injected with cell-wall preparations or heat-killed bacteria stopped gaining weight during the first two weeks of the experiment, appeared unwell, with ruffled fur, and were lethargic. When inoculation of the irritants ceased, the animals started to regain weight and appeared healthy. Both the heat-killed bacteria and their cell-wall preparations, in addition to inducing these characteristics, also caused the death of $40 \%$ of the animals. Autopsy of the animals injected with these toxic preparations showed the presence of peritonitis, with an inflammatory exudate, massive adhesions of the organs in the peritoneal cavity, numerous granulomas and splenomegaly. 


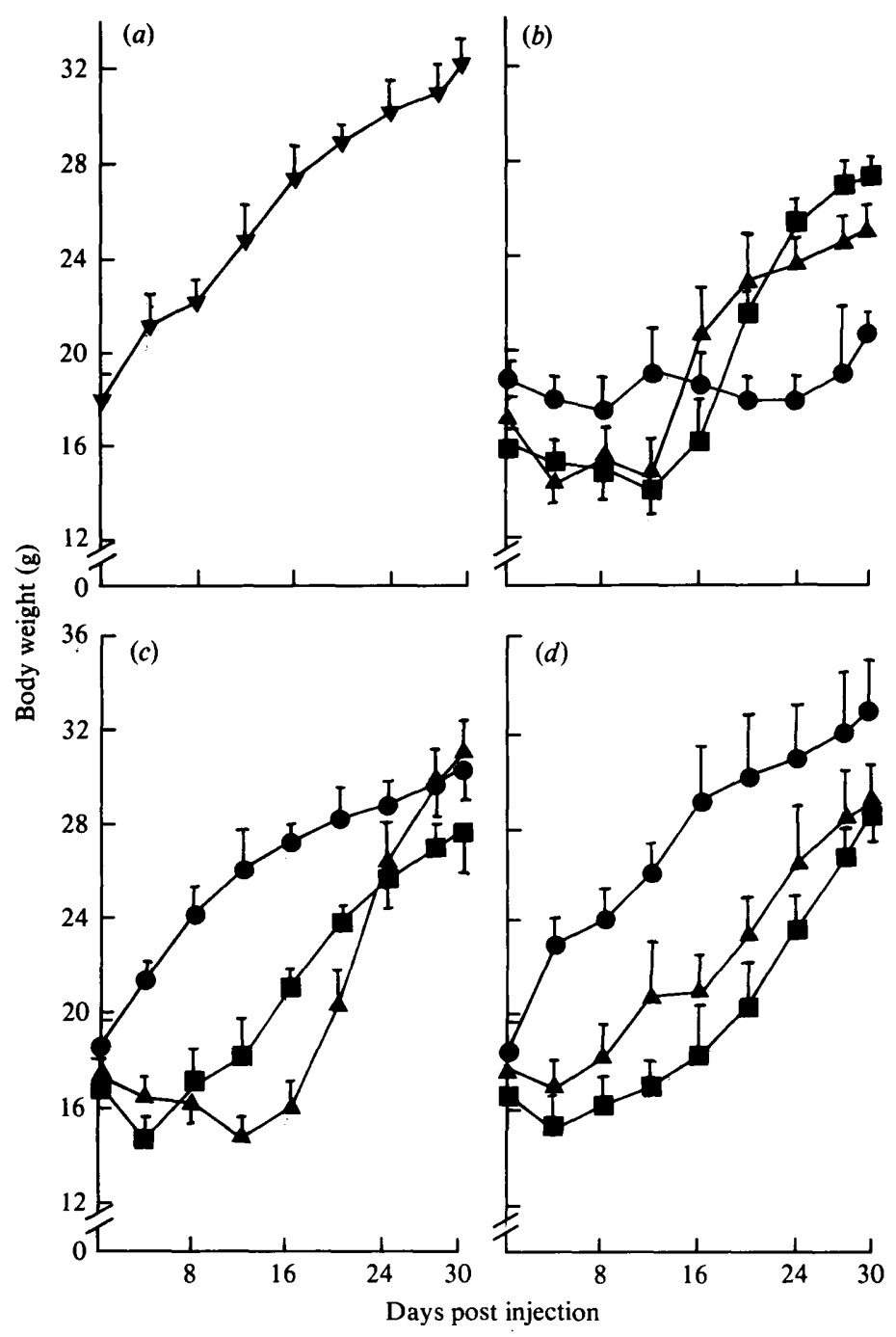

Fig. 1. Mean body weight $( \pm S D)$ of groups of ten mice at various times after intraperitoneal injection (in mineral oil) of five doses of $200 \mu \mathrm{g}$ of killed bacteria $(\square)$, cell walls $(\Delta)$ and lipid extract $(O)$, from $N$. brasiliensis $(b), A$. madurae $(c)$ and 'S. pelletieri' $(d)$, at $2 \mathrm{~d}$ intervals starting at day 0 . The control group $(a)$ was injected with mineral oil alone. It is not possible to examine the results statistically because of the decreasing number of animals in each group as seen in Table 1. Results are from a typical experiment.

A similar response pattern to that obtained after the inoculation of animals with various $A$. madurae preparations was also observed after inoculation of ' $S$. pelletieri', i.e. no toxic effects with the lipid extract and induction of weight loss and mortality by heat-killed micro-organisms or cell walls (Fig. 1d, Table 1).

Mice injected with the lipid extract, cell walls and heat-killed bacteria of $N$. brasiliensis showed an initial decrease in body weight after inoculation and stopped gaining weight for $16 \mathrm{~d}$, slowly recovering thereafter (Fig. $1 b$ ). The survival rate of the animals injected with cell walls or heat-killed bacteria was $60 \%$, whereas the rate for animals inoculated with the lipid extract was $30 \%$ after $30 \mathrm{~d}$ (Table 1$)$. 
Table 1. Lethal effect of killed bacteria, cell-wall preparations and lipid extracts in mice given intraperitoneal inocula

\begin{tabular}{|c|c|c|c|c|c|c|c|c|c|}
\hline \multirow[b]{2}{*}{ Organism } & \multirow{2}{*}{$\begin{array}{l}\text { Material } \\
\text { injected* }\end{array}$} & \multicolumn{7}{|c|}{ Deaths in groups of 10 mice on dayt: } & \multirow[b]{2}{*}{ Total } \\
\hline & & 8 & 12 & 16 & 20 & 24 & 28 & 30 & \\
\hline N. brasiliensis & $\begin{array}{l}\text { Control } \\
\text { Killed bacteria } \\
\text { Cell walls } \\
\text { Lipid extract }\end{array}$ & $\begin{array}{l}0 \\
0 \\
0 \\
1\end{array}$ & $\begin{array}{l}0 \\
2 \\
1 \\
2\end{array}$ & $\begin{array}{l}0 \\
1 \\
0 \\
2\end{array}$ & $\begin{array}{l}0 \\
0 \\
1 \\
0\end{array}$ & $\begin{array}{l}0 \\
0 \\
1 \\
0\end{array}$ & $\begin{array}{l}0 \\
1 \\
0 \\
1\end{array}$ & $\begin{array}{l}0 \\
0 \\
1 \\
1\end{array}$ & $\begin{array}{l}0 \\
4 \\
4 \\
7\end{array}$ \\
\hline A. madurae & $\begin{array}{l}\text { Killed bacteria } \\
\text { Cell walls } \\
\text { Lipid extract }\end{array}$ & $\begin{array}{l}0 \\
0 \\
0\end{array}$ & $\begin{array}{l}1 \\
2 \\
0\end{array}$ & $\begin{array}{l}2 \\
1 \\
0\end{array}$ & $\begin{array}{l}0 \\
1 \\
0\end{array}$ & $\begin{array}{l}1 \\
0 \\
0\end{array}$ & $\begin{array}{l}0 \\
0 \\
0\end{array}$ & $\begin{array}{l}0 \\
0 \\
0\end{array}$ & $\begin{array}{l}4 \\
4 \\
0\end{array}$ \\
\hline 'S. pelletieri' & $\begin{array}{l}\text { Killed bacteria } \\
\text { Cell walls } \\
\text { Lipid extract }\end{array}$ & $\begin{array}{l}0 \\
0 \\
0\end{array}$ & $\begin{array}{l}1 \\
0 \\
0\end{array}$ & $\begin{array}{l}1 \\
1 \\
0\end{array}$ & $\begin{array}{l}0 \\
0 \\
0\end{array}$ & $\begin{array}{l}0 \\
0 \\
0\end{array}$ & $\begin{array}{l}0 \\
0 \\
0\end{array}$ & $\begin{array}{l}0 \\
0 \\
0\end{array}$ & $\begin{array}{l}2 \\
1 \\
0\end{array}$ \\
\hline
\end{tabular}

* Mice were given five doses of $200 \mu \mathrm{g}$ of each preparation at $2 \mathrm{~d}$ intervals starting at day 0 . The control group was injected with mineral oil alone.

† For convenience, the data were recorded at $4 \mathrm{~d}$ intervals. Results are from a typical experiment.

The results obtained were reproducible from experiment to experiment: the values varied slightly from one experiment to the next but the general pattern of body weight curves and survival rate were very similar. It was not possible to examine the results statistically because of the decreasing numbers of animals in each group as seen in Table 1.

Fractions F1, F2 and F3 obtained from cell walls of 'S. pelletieri', $A$. madurae and $N$. brasiliensis after alkali treatment were also assayed for toxicity in mice by the procedure described above. The alkali-insoluble fractions Fl were toxic, causing wasting symptoms and rapid loss of body weight. The initial chemical analysis of these toxic fractions showed that they were composed mainly of polysaccharide. Mice injected with the alkali-soluble fractions $F 2$ and F3 showed no signs of illness and gained weight normally.

The lipid extracts obtained from the three micro-organisms and a mixture of known standard lipids were chromatographed on TLC plates using solvent $\mathbf{A}$. This solvent system resolved the lipid mixtures, indicating the presence of ketone, menaquinone, triglycerides and palmitic acid in the lipid extracts obtained from all three micro-organisms. On the other hand, mycolic acid was only detected in the lipid extract of $N$. brasiliensis. When solvent B was used, a lipid component present in the extract obtained from $N$. brasiliensis migrated on TLC in a similar manner to the trehalose dimycolate standard. A similar compound was not detected in the lipid extracts from $A$. madurae and ' $S$. pelletieri'.

\section{DISCUSSION}

The results obtained here clearly indicate that heat-killed $A$. madurae, 'S. pelletieri' and $N$. brasiliensis contain components with toxic and inflammatory properties, since they produced loss of body weight, formation of inflammatory exudates, granulomas and death when inoculated into mice. Removal of the lipids of these micro-organisms by solvent treatment did not alter the toxicity of the cell wall when compared to that observed in animals inoculated with heat-killed micro-organisms. On the other hand, when the lipid extracts were inoculated, only that from $N$. brasiliensis was highly toxic to mice.

Among the lipid constituents found in Nocardia, the most characteristic one is trehalose dimycolate (Silva et al., 1979; Ioneda et al., 1981). This substance, initially demonstrated in Mycobacterium tuberculosis (Bloch, 1950; Noll et al., 1956) and later in Corynebacterium (Ioneda et al., 1963) and Nocardia (Ioneda et al., 1970), consists of two molecules of mycolic acid ( $\alpha$ branched and $\beta$-hydroxylated acid-containing carbon chains which vary in length from organism to organism) bound to the disaccharide trehalose. The glycolipid isolated from mycobacteria is directly involved in the formation of granulomas in tuberculosis (Bekierkunst, 1968; Bekierkunst et al., 1969) and has adjuvant (Saito et al., 1976), immunostimulant (Yarkoni et al., 1977; Parent et al., 1977) and antitumour properties (Bekierkunst et al., 1971). These 
effects, in addition to its toxicity, suggest its participation in the host-parasite relationship at different levels.

In previous studies it was demonstrated that Mycobacterium bovis BCG without the glycolipid trehalose dimycolate on the external part of their cell walls were more susceptible to phagocytosis and were eliminated more rapidly by the host. They did not induce granuloma formation, and had a low capacity for nonspecific immunostimulation and a reduced ability to induce a delayed hypersensitivity response (Silva et al., 1984, 1985). In view of these considerations, and especially considering our work with BCG, the pathogenic mechanism of nocardia species may well be similar, since they possess the glycolipid trehalose dimycolate. Species of the genera Streptomyces and Actinomadura, which cause infections similar to those induced by Nocardia and Mycobacterium, have no lipid components similar to mycolic acid or trehalose dimycolate. Thus, the toxic components present in these organisms must be different.

This work was supported by grants from Fundação de Amparo à Pesquisa do Estado de São Paulo (FAPESP process no. 84/1650-4 and Conselho Nacional de Pesquisa (CNPq - process nos 407701/85 BM and 30.0351/81).

\section{REFERENCES}

Bekierkunst, A (1968). Acute granulomatous response produced in mice by trehalose-6,6'-dimycolate. Journal of Bacteriology 95, 952-961.

Bekierkunst, A., LeVIJ, I. S., Yarkoni, E., Vilkas, E., ADAM, A. \& LeDERER, E. (1969). Granuloma formation induced in mice by chemically defined mycobacterial fraction. Journal of Bacteriology 100, 95-102.

Bekierkunst, A., LeviJ, I. S., Yarkoni, E., Vilkas, E. \& LEDERER, E. (1971). Suppression of urethaninduced lung adenomas in mice treated with trehalose-6,6'dimycolate (cord factor) and living BCG. Science 174, 1240-1242.

BLOCH, H. (1950). Studies on the virulence of tubercle bacilli. Isolation and biological properties of a constituent of virulent organisms. Journal Experimental Medicine 91, 197-217.

Conant, N. F., SMith, D. T., BaKer, R. D. \& Callaway, J. L. (1971). Actinomycotic mycetoma. In Manual of Clinical Mycology, 3rd edn, pp. 62-83. Philadelphia: W. B. Saunders Co.

Cross, T., Rowbothan, T. J., Mishustin, E. N., Zeprer, E. Z., Antoine-Portales, F., SchaAl, K. P. \& BICKENBACH, H. (1976). The ecology of nocardioform actinomycetes. In The Biology of the Nocardiae, pp. 337-367. Edited by M. Goodfellow., G. H. Brownell \& J. A. Serrano. London: Academic Press.

Ioneda, T., Lenz, M. \& Pudles, J. (1963). Chemical constitution of a glycolipid from Corynebacterium diphtheriae PW8. Biochemical and Biophysical Research Communications 13, 110-114.

IONEDA, T., LeDERER, E. \& RoZANIS, J. (1970>. Sur la structure des diesters de trehalose ('cord factors') produits par Nocardia asteroides et Nocardia rhodochrous. Chemistry and Physics of Lipids 4, 375392.

Ioneda, T., Silva, C. L. \& Gesztesi, J. L. (1981). Mycolic acid containing glycolipids of nocardiae and related organisms. In Actinomycetes (Zentralblatt für Bakteriologie Suppl. 11), pp. 401-406. Edited by K. P. Schaal \& G. Pulverer. Stuttgart \& New York: Gustav Fischer.

Kanetsuna, F., Carbonell, L. M., Azuma, I \& Yamamura, Y. (1972). Biochemical studies on the thermal dimorphism of Paracoccidioides brasiliensis. Journal of Bacteriology 110, 208-218.

Noll, H., Bloch, H., Asselineau, J. \& Lederer, E. (1956). The chemical structure of cord factor of Mycobacterium tuberculosis. Biochimica et biophysica acta 20, 299-309.

Parant, M., Parant, F., Chedid, L., Drapier, J. C., Petit, J. F., Wietzerbin, J. \& Lederer, E. (1977). Enhancement of nonspecific immunity to bacterial infection by cord factor (6,6'-dimycolate of trehalose). Journal of Infectious Diseases 135, 771-777.

RIPPON, J. W. (1982). Introduction to the pathogenic actinomycetes. In Medical Mycology. The Pathogenic Fungi and the Pathogenic Actinomycetes, 3rd edn, pp. 15-29. Philadelphia: W. B. Saunders Co.

Saito, R., Tanaka, A., Sugiyama, K., Azuma, I., Yamamura, Y., Kato, M. \& Goren, M. (1976). Adjuvant effect of cord factor, a mycobacterial lipid. Infection and Immunity, 13, 776-781.

Silva, C. L. \& IONEDA, T. (1977a). Isolation and identification of menaquinone and acylglycerols in the acetone-soluble lipids from Nocardia rhodochrous. Revista de microbiologia 8, 39-42.

Silva, C. L. \& IONEDA, T. (1977b). Purification and characterization of mononocardomycoloyl-glycerol from Nocardia rhodochrous. Chemistry and Physics of Lipids 20, 217-223.

Silva, C. L., Gesztesi, J. L. \& Ioneda, T. (1979). Trehalose mycolates from Nocardia asteroides, Nocardia farcinica, Gordona lentifragmenta and Gordona bronchialis. Chemistry and Physics of Lipids 24, $17-25$.

Silva, C. L., Ekizlerian, S. M. \& Fazioli, R. A. (1984). Removal of the external glycolipid layer reduces the toxic and immunostimulant properties of Bacillus Calmette-Guérin. Brazilian Journal of Medical and Biological Research 17, 378.

Silva, C. L., Ekizlerian, S. M. \& Fazioli, R. A. (1985). Role of cord factor in the modulation of infection caused by mycobacteria. American Journal of Pathology 118, 238-247.

YARKoni, E., WANG, L. \& BeKIERKunST, A. (1977). Stimulation of macrophages by cord factor and by heat-killed and living BCG. Infection and Immunity 16, 1-8. 